\title{
$B$ cell activating factor in juvenile onset systemic lupus erythematosus, looking beyond the B cell
}

\author{
Ella Richards", Angela Midgely, Thomas Morgan, Michael Beresford \\ From 21st European Pediatric Rheumatology (PReS) Congress \\ Belgrade, Serbia. 17-21 September 2014
}

\section{Introduction}

Increased B cell activating factor (BAFF) in the serum of juvenile-onset systemic lupus erythematosus (JSLE) patients is thought to be key to the survival of autoreactive $B$ cells. BAFF signals through three receptors, BAFF-R, BCMA and TACI, activating the NF- $\kappa$ B pathway. Belimumab is a human monoclonal antibody against BAFF that has recently become the first drug licensed for the treatment of SLE in 50 years. In order to investigate the potential effect of BAFF inhibition on the wider immune system, receptor expression was investigated in another SLE pathogenic cell, the T lymphocyte.

\section{Objectives}

To determine $\mathrm{T}$ cell expression of the BAFF-R and BCMA receptors and the effect of BAFF on cell survival in JSLE patients compared to healthy paediatric controls.

\section{Methods}

Lymphocytes were isolated from JSLE patients and healthy paediatric controls. Cells were dual immunostained with flurochrome conjugated monoclonal antibodies for BAFF receptors, BAFF-R or BCMA (FITC labelled) as well as the $\mathrm{T}$ cell marker CD3 (PECy5 labelled) allowing detection of $\mathrm{T}$ cells expressing the receptor to be identified by flow cytometry $(n=8)$. Survival of $T$ cells was assessed by quantifying the degree of apoptosis taking place using an Annexin V stain after 4 hours incubation with recombinant human BAFF (rhBAFF); receptor expression was analysed as stated previously $(n=5)$. Results expressed as: mean + /-SEM. Statistical significance was taken when $\mathrm{p}$ values were $<0.05$.

\section{Results}

The total lymphocyte population was found to express both BAFF-R and BCMA receptors similarly in JSLE patients (BAFF-R 14.8\%+/-3.15; BCMA 4.98+/-0.86) and controls (BAFFR 8.2\%+/-1.6; BCMA 6.07+/-0.87). T cells also displayed similar expression (JSLE: BAFF-R 3.37\% +/-0.42; BCMA: 1.91+/-0.31; Controls: BAFF-R, 3.27\% +/-0.82; BCMA, 2.34+/-0.96) with BAFF-R receptor expressed more frequently than BCMA in both cohorts. Importantly, incubation with rhBAFF led to an increase in the survival of $T$ cells when analysing both JSLE patients and controls together $(\mathrm{n}=9$ pre treatment $25 \%+/-3.1$; rhBAFF treated, $19.7+/-2.7 ; \mathrm{p}=0.008)$, and separately (JSLE: pre treatment, $31.04 \%+/-2.34$; rhBAFF treated, $25.03 \%+/-1.13, \mathrm{p}=0.043$; Control: pre-treatment, $17.59 \%$ +/-4.27; rhBAFF treated, $12.99 \%+/-4.24, \mathrm{p}=0.068$ ). rhBAFF also significantly down-regulated BAFF-R expression in lymphocytes of both groups $(\mathrm{n}=9)$ Pre-treated; $11.51 \%$ +/-2.00; rhBAFF treated: $5.02 \%+/-0.907$ ) . Finally a positive correlation with the disease activity score SLEDAI was observed with JSLE patient BCMA receptor expression on both lymphocytes (correlation coefficient $\mathrm{r}^{2}=0.6 \mathrm{p}=0.024$ ) and $\mathrm{T}$ cells $\left(\mathrm{r}^{2}=0.67 ; \mathrm{p}=0.013\right)$.

\section{Conclusion}

This study has demonstrated that $\mathrm{T}$ cells from paediatric patients express BAFF receptors as previously noted in adults. Interestingly both BAFF-R and BCMA receptors were detected. Whether by direct signalling or an indirect mechanism, BAFF has been shown to reduce apoptosis of $\mathrm{T}$ cells in both JSLE patients and healthy controls. This observation challenges the notion that $\mathrm{T}$ cells exclusively express BAFF-R highlighting that BCMA expression on $T$ cells could be unique to the immature immune system. Importantly, these data indicate that this 'B cell survival

Institute of Child Health, Univeristy of Liverpool, Liverpool, UK 
factor' is also capable of influencing the survival of T cells in vitro. Aberrant $\mathrm{T}$ cell homeostasis is a pathogenic feature of SLE. To understand how increased T cell survival may affect the disease, it is important to understand receptor expression on different $\mathrm{T}$ cell subsets, including the inflammatory Th17 and anti-inflammatory Tregs. Allowing a clearer picture of how BAFF inhibition may affect the wider immune system.

\section{Disclosure of interest}

None declared.

Published: 17 September 2014

doi:10.1186/1546-0096-12-S1-P112

Cite this article as: Richards et al.: B cell activating factor in juvenile onset systemic lupus erythematosus, looking beyond the B cell. Pediatric Rheumatology 2014 12(Suppl 1):P112.
Submit your next manuscript to BioMed Central and take full advantage of:

- Convenient online submission

- Thorough peer review

- No space constraints or color figure charges

- Immediate publication on acceptance

- Inclusion in PubMed, CAS, Scopus and Google Scholar

- Research which is freely available for redistribution

Submit your manuscript at www.biomedcentral.com/submit
C Biomed Central 